\title{
Остри риносинуити при децата
}

\author{
Сп. Тодоров дм \\ Катедра УНГ болести при УМБАЛ “Царица Йоанна - ИСУЛ” ЕАД София
}

\begin{abstract}
Резюме
Острият риносинуит в детската възраст е често заболяване, което за първи път се диагностицира и лекува от общопрактикуващите лекари. В болшинството от случаите се касае за вирусна инфекция, която не налага антибиотично лечение. Масовото и неправилно приложение на антибиотици може да доведе до резистентност и оскъпява излишно лечението. В статията се дават особеностите в клиничното протичане, диагнозата, диференциалната диагноза и лечението на острите риносинуити при децата.
\end{abstract}

\begin{abstract}
The acute rhinosinuitis is a frequent disease among pediatric population and is subject of initial treatment by general practitioners. The majority of cases it's related to viral etiology, which doesn't require an antibiotic treatment. The common administration of antibiotics could lead to antibiotic resistance and raise the cost of treatment unnecessary. The article focuses on specific characteristics of clinical course, diagnostic process, differential diagnosis and treatment of pediatric acute rhinosinuitis.
\end{abstract}

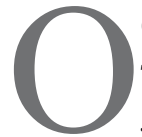

стрите вирусни инфекции на горните дихателни пьтища (ГДП) са най-честите заболявания в детската възраст. Годишно всяко дете боледува 3 - 8 пъти от остро респираторно заболяване ${ }^{1}$. До $98 \%$ от тези инфекции са причинени от вируси и само в около $2 \%$ от случаите при децата се доказва бактериален причинител ${ }^{2}$.

Тъй като лигавицата на околоносните кухини е непосредствено продължение на носната лигавица, всяко остро вирусно респираторно заболяване ще доведе до възпалителни промени и в синусите. При компютьрно-томографско изследване при $90 \%$ от тези болни се установяват данни за синуит. Болшинството от тези синуити остават недиагностицирани поради липса на специфична симптоматика и оздравяват спонтанно.

Острите риносинуити при децата протичат с редица особености, които трябва да се знаят, за да не се допускат грешки в диагностиката и лечението.

1. Анатомичното развитие на отделните синуси определя до голяма степен времето на поява и клиниката на синуита при децата ${ }^{3}$. След раждането най-добре развити са предните етмоидални клетки. Максиларният синус представлява хоризонтална цепнатина, която до 1-годишна възраст достига до кучешкия зъб, на 2-годишна възраст - до втория предкътник, на 10 години - до кътника, и едва към 15-тата година се оформя окончателно. Фронталният синус е резултат от нарастване на една етмоидална клетка и се оформя след 6 - 8-годишна възраст. Сфеноидалният синус се развива през първата година от живота, 
но се оформя окончателно към 15-годишна възраст.

2. Лигавицата, която покрива детските синуси е относително по-дебела и е склонна към оточни и хиперпластични реакции. Отокът запушва естествените отвори на синусите и причинява задръжка на секрета, промени в газовия състав и налягането в синусите, което в крайна сметка уврежда дейността на въсеносния епител на лигавицата. Най-критичното място е т.н. остеомеатален комплекс, който се намира в средния носов ход и където са изходните отверстия на предната група синуси ${ }^{4}$.

3. Хипертрофията на аденоидната вегетация играе съществена роля при възникване на синуита при децата. От една страна синуитьт може да бъде първичен, а хипертрофията да се дължи на възпалително дразнене от стичащия се назад инфектиран секрет. От друга страна, първичното увеличение на аденоидната вегетация нарушава нормалното носно дишане, той се задържа в носните ходове, инфектира се и благоприятствува появата на синуит.

4. Имунологично незрелият детски организъм е податлив на различни вирусни инфекции. Някои от вирусите, напр. риновирусите не увреждат сериозно епитела на лигавицата, докато други (грипни, парагрипни, аденовируси) причиняват сериозни епителни увреждания и улесняват бактериалната суперинфекция. При много деца с остри риносинуити е доказан имунодефицит на $\mathrm{IgG}^{5}$.

5. Алергията при децата нерядко се съчетава с прояви на остьр синуит. Според Fior ${ }^{6}$ инфекцията и алергията са двата най-важни фактора в етиопатогенезата на детския риносинуит.

6. Други причини, специфични за детската възраст, които обуславят появата на синуит, са чуждите тела в носа и плуването в замърсени водни басейни. При чуждите тела синуитът е едностранен, а секретът е с неприятна миризма.

\section{Клиника на острия риносинуит при децата}

Синуитьт при децата е риногенен и по-рядко - хематогенен (след остри заразни болести). Започва най-често като остра вирусна инфекция с повишена температура, запушен нос, водниста секреция от носа, кашлица, понякога епистаксис и симптоми на остър отит. В следващите $4-5$ дни температурата спада, носната секреция се сгъстява и намалява, докато запушването на носа и кашлицата могат да продължат и през следващите 14 дни. Установено е, че средната продължителност на ОВИ при 2 - 3 годишни деца, отглеждани в къщи, е 6.6 дни, докато при такива в детски ясли и градини - $8-9$ дни 7 . Едва при бактериална суперинфекция се проявяват характерните за синуита симптоми, а това става след 10-ия ден от началото на заболяването.

Характерна особеност на детския синуит е, че рядко се наблюдава изолирано възпаление само на един синус. По правило се развива максилоетмоидит или пансинуит.

Колкото по-малко е детето, толкова по-неспецифична е клиничната картина на синуита, като на преден план изпъкват общите симптоми температура, неспокойствно, раздразнителност, сънливост, кашлица.

При някои деца синуитът не започва остро, a още от началото протича с продължителна субфебрилна температура, гноевиден секрет от носа, който при стичането си назад обуславя влажната и продължителна кашлица. Кашлицата е най-силна сутрин и през деня. Детето не изглежда тежко болно, но е бледо, отпуснато и вяло. Носното дишане е затруднено, децата спят с отворена уста и хъркат ${ }^{8}$.

Острият синуит при децата често се сьпровожда от блед оток на клепачите, без това да означава орбитално усложнение. Понякога обаче синуитът се проявява направо с някое орбитално усложнение, поради близките анатомични взаимоотношения между орбитата и съседните на нея синуси.

Обективното изследване показва затруднено носно дишане, което най-често е двустранно. Ноздрите са мацерирани, нерядко с рагади по тях. С предна риноскопия се вижда обилен слузно-гноен ексудат в носните ходове, който се стича назад към гърлото. Носната лигавица е зачервена и оточна, долните носни конхи са хипертрофични.

Диагнозата на синуита в детската възраст е значително по-трудна отколкото при въ3растните. Неспокойствието на детето по време на прегледа, тесните носни ходове, набъбналата носна лигавица и приложеното предварително 
антибиотично лечение значително затрудняват диагнозата. Бактериограмата от носния секрет не е показателна за бактериалния произход на синуита у децата. Диагнозата на последния се базира най-често на подробната анамнеза и физикалното изследване. Макар че ,златният стандарт" за диагнозата да е директното вземане на материал от синуса чрез пункция, при децата тази манипулация не се препоръчва ${ }^{9}$. От допълнителните методи на изследване засега най-точни данни дава рентгенографията на околоносните кухини. Рентгенологични данни за синуит има, когато:

- налице е хомогенно засенчване на съответния синус

- има хидроаерична сянка (ниво линия)

- при надебеление на лигавицата на синуса над 4-6 мм.

Трябва да се има предвид, че рентгеновата находка при децата крие много подводни камъни, поради големия брой фалшиви положителни и отрицателни резултати. Погрешното интерпретиране на рентгенограмите може да се дължи на ниското им качество, поради неспокойствие и мърдане на детето по време на снимката, на лош центраж, на недоразвитите още синуси, имитиращи засенчване и пр. Найточни резултати дава компютьрната томография, която все още не се прилага в ежедневната практика.

\section{Диференциална диагноза}

Във връзка със затрудненото носно дишане и обилната секреция в диференциално диагностично отношение може да се мисли за алергичен ринит, увеличена аденоидна вегетация и по-рядко за полипи в носа, тумори и изкривена носна прегреда.

Във връзка с упоритото главоболие, от което се оплакват някои деца, много родители считат, че това се дължи на синуит и търсят консултация с оториноларинголог. Това са най-често деца в училищна възраст, при които болките са локализирани в челната област, зад очните ябълки или в слепоочията. Главоболието започва към обяд и се засилва вечер. Ако при прегледа не се установят данни за синуит, такива деца трябва да се насочат към офталмолог поради възможността главоболието да се дължи на очна аномалия (далекогледство, астигматизъм и др. ).
Лечението на острия риносинуит при децата е консервативно, тъй като се касае за възпаление само на лигавицата.

То включва следните групи медикаменти: антибиотици, назални деконгестанти, секретолитици и антихистамини.

Антибиотици. Те заемат водещо място в медикаментозното лечение на острия бактериален синуит. Ефикасността им зависи на първо място от подходящия спектър на действие, който се определя от вида на причинителя. Установено е, че при децата най-честите причинители на острия риносинуит са: Str. pneumoniae (30 - 40\%), H. influenzae $(15-20 \%)$ и М. catarrhalis $(10-15 \%)$. По правило инфекцията е монобактериална, но в 26-30\% от случаите могат да се изолират и повече бактерии ${ }^{10}$.

Вторият критерий за избор на антибиотик е анамнезата за предшествуващо лечение с антибиотици, поради повишен риск от резистентност. От тази гледна точка децата се разделят на две групи:

- Такива с лека до умерена тежест на синуита, които не са лекувани с антибиотик през последните 4 - 6 седмици.

- Такива с умерени симптоми, лекувани с антибиотици, или такива с тежка симптоматика, независимо от предшествуващото антибиотично лечение.

Лечението на първата група болни е уместно да се проведе с високи дози Ампицилин - 90 мг/кг дневно. С успех се прилагат и високи дози цефалоспорини от първа генерация (Цефалексин 100 мг/кг дневно) с уговорката, че те имат по-слабо действие върху Str. pneumoniae. При алергия към бета-лактамните антибиотици се прилагат Кларитромицин или Азитромицин.

При болните от втората група най-подходящи са високи дози на Amoxicillin+Ac. clavulanicum $\left(\right.$ Augmentin $\left.{ }^{\circledR}\right)$ или Cefuroxime axetil $\left(\right.$ Zinnat $\left.^{\circledR}\right)$. Аугментинът трябва да бъде в доза 90 мг/кг дневно за амоксицилина и 6.4 мг/кг тегло дневно за клавулановата киселина. Зинатьт трябва да бъде минимум 40 мг/кг дневно.

Продължителността на лечението не трябва да бъде по-малка от 8 - 10 дни.

Назални деконгестантни. С техния отбъбващ ефект върху носната лигавица те отпушват отворите на синусите и подобряват дренажа им. За да окажат това действие, носните капки трябва да влязат в интимен контакт с носната 
лигавица, което е невъзможно при наличие на обилен секрет в носните ходове. Ето защо преди поставяне на капките носът трябва да се издуха добре, а при деца, които не могат да сторят това, секретът се аспирира с помпичка.

Наред с отбъбващия ефект, носните капки от групата на имидазолите (ксилометазолин, олинт) имат и някои странични действия, които ограничават тяхната употреба в детската възраст. Те са токсични за новородени и кърмачета, у които могат да причинят възбуденост, гърчове и кома. Освен това забавят и дори преустановяват движението на ресничките в епитела, с което затрудняват естественото елиминиране на носния секрет. Поради вазоконстрикторния им ефект те намаляват кръвотока към лигавицата, a с това и дифузията на антибиотика и другите лечебни средства в синусите. Дълготрайното им приложение крие опасност от развитие на медикаментозен ринит и привикване. Поради всичко това, приложението на имидазоловите носни капки при деца трябва да се ограничи само за случаите със силно запушен нос и то за не повече от 5-6 дни, а във всички останали случаи да се прилагат промивки с физиологичен серум ${ }^{11}$. Секретолитици. При острия риносинуит се наблюдава цялостно разстройство на мукоцилиарния клирънс. Движението на ресничките се забавя и спира, вискозитетьт на секрета се увеличава. Това води до затруднен дренаж и задръжка на ексудата в синусите.

Секретолитиците активират дейността на чашковидните клетки и жлези, които започват да продуцират по-голямо количество и по-рядък секрет. Освен това се активира движението на ресничките и се улеснява изхвърлянето на секрета от синуса. Много секретолитици притежават допълнително антисептично и противовъ3-

\section{Литература}

1. Wald ER. Sinuitis in children. N Engl J Med 1992; 326: 319-23.

2. Wald ER. Sinuitis. Pediatr Ann 1998; 27: 811-8.

3. Zacharisen MC, Kelly KS. Allergic and infectious pediatric sinuitis. Pediatr Ann 1998; 27: 759-66.

4. Fagnan LJ. Acute sinuitis: a cost-effective approach to diagnosis and treatment. Am Fam Physician 1998; 58: 1795-802; 805-6.

5. Lusk RP, Stankiewicz JA. Pediatric rhinosinuitis. In: Anou JB, ed. Report of the Rhinosinuitis Task Force Committee Meeting. Otolaryngol. Head Neck Surg 1977; 117 (suppl) 53-57.

6. Fior R. Betrachtungen uber das sogenante „katarrhalische Kind“. HNO-Praxis 1980; 1: 9-18.

7. Fireman P. Diagnosis of sinuitis in children. Emphasis on the history and physical examination. J Allergy Clin Immunol 1992; 90: 433-6. палително действие. В практиката се използват Бромхексин, Амброксол, Геломиртол, Еуреспал, АСС и др. секретолитици.

Антихистамини. Установено е, че антихистамините сгъстяват носния секрет и затрудняват елиминирането му, поради което много лекари се въздържат от приложението им при острия риносинуит. От друга страна обаче, практиката е показала тяхното благоприятно действие при алергични пациенти с остьр риносинуит. При децата с успех ce прилагат Лоратадин (Claritine ${ }^{\circledR}$ ), Цетиризин $\left(\right.$ Zyrtec $\left.^{\circledR}\right)$, Дезлоратадин (Aerius $\left.{ }^{\circledR}\right)$, Левоцетиризин $\left(\mathrm{Xyzal}{ }^{\circledR}\right)$, при които страничните действия са сведени до минимум, прилагат се веднаж дневно и имат бързо и продължително действие.

\section{Заключение}

Въпреки многобройните публикации във връзка с острия бактериален синуит, понастоящем липсват универсални правила за диагноза и лечение на това заболяване. Това касае особено синуита в детската възраст, който се отличава с редица особености в клиничното протичане, диагнозата и лечението. Най-честата грешка е прилагане на антибиотици при вирусна генеза на заболяването. В тези случаи лечението трябва да се фокусира върху намаляване отока на лигавицата, освобождаване на естествените отвори на синусите, подобряване на дренажа и втечняване на секрета. При данни за бактериална инфекция изборьт на антибиотик трябва да става на базата на общото състояние на детето, по дозираната резистентност и наличието на медикаментозна алергия. При правилен избор на антибиотик и приложението му във висока доза и достатъчна продължителност, острият бактериален синуит оздравява напълно и се избягват опасностите от усложнения и хронифициране на синуита.

8. Otten EWA, Grotte JJ. Treatment of chronic maxillary sinuitis in children. Int J Pediatr Otorhinolaryngol 1988;15: 269-78.

9. Berg O, Carenfelt C. Analysis of simptoms and clinical signs in the maxillary sinus empiems. Acta Otolaryngol 1988; 105: 343-9.

10. Wald ER. Microbiology of acute and chronic sinuitis in children and adults. Am J Med Sci 1998; 316: 13-20.

11. Brook I, Gooch WM, Jenkins SG, Pichichero ME, Reiner SA, Sher L, Yamauchi T. Medical management of acute bacterial sinuitis. Recommendations of a clinical advisory committee on pediatric and adult sinuitis. Ann Otol Rhinol Laryngol 2000; 109 (suppl 182 p3): 1-20. 